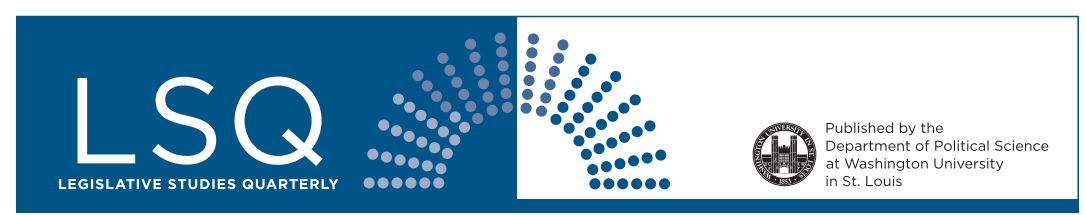

\author{
RAFFAELE ASQUER \\ Independent Researcher \\ MIRIAM A. GOLDEN \\ European University Institute \\ BRIAN T. HAMEL \\ University of California, Los Angeles
}

\title{
Corruption, Party Leaders, and Candidate Selection: Evidence from Italy
}

Research indicates that voters are not particularly effective at removing corrupt politicians from office, in part because voters make decisions on the basis of many competing factors. Party leaders are much more single-minded than voters and will choose to deselect implicated legislators if it means maintaining a positive party reputation and improving the odds of winning a legislative majority. We examine renominations to Italy's legislature in two periods marked by corruption. We compare these renomination patterns with those from the prior legislature, when corruption lacked political salience. Our analysis shows that incumbent renominations are negatively associated with the number of press mentions that link the incumbent to corruption-but only when corruption is salient to the public. Our study highlights the importance of party leaders in forcing malfeasant legislators out of office - and reducing corruption - and redirects attention from voters to political elites as a critical channel in enforcing democratic accountability.

The theory of democratic accountability draws on the idea that the fundamental role of voters is to threaten elected politicians with loss of office if they do not perform adequately (Ferejohn 1986; Przeworski, Stokes, and Manin 1999). The theory is motivated by a bottom-up perspective that sees the evolution of democratic practices unfolding through the increasingly effective work of an informed, educated, and vigilant citizenry. Emerging from this framework is a large literature on whether voters punish politicians implicated in scandals, especially those involving political corruption. Summarizing, these studies report two key findings. First, in survey experimental settings, voters

LEGISLATIVE STUDIES QUARTERLY, 0, 0, December 2019

DOI: $10.1111 /$ ssq.12259

(C) 2019 Washington University in St. Louis 
overwhelmingly sanction corrupt politicians (Boas, Hidalgo, and Melo 2019; Klašnja and Tucker 2013; Weitz-Shapiro and Winters 2013, 2017; Winters and Weitz-Shapiro 2016). This suggests a general norm against corruption: citizens see corruption as wrong and view those engaged in it as unfit for office. But studies of actual voting behavior and electoral returns show that though malfeasant politicians often receive fewer votes than those not accused of corruption, the former still usually win reelection (Anduiza, Aina, and Muñoz 2013; Basinger 2013; Boas, Hidalgo, and Melo 2019; Carlson and Reed 2018; Chang, Golden, and Hill 2010; Chong et al. 2015; Hamel and Miller 2019; Klašnja, Tucker, and DeeganKrause 2016; Peters and Welch 1980; Welch and Hibbing 1997). For example, Basinger (2013) shows that 73\% of scandal-tainted legislators in the US House won their next primary election, and of those, $81 \%$ won the next general election.

Voters, in short, are not particularly effective at removing corrupt politicians from office. New work (e.g., Boas, Hidalgo, and Melo, 2019) has sought to explain why this is - that is, why corruption in and of itself is not enough to trigger effective political sanctioning. One plausible interpretation is that voters' goals are multidimensional, and they make electoral choices on the basis of many factors. Partisanship, racial and ethnic identity, and personal loyalties loom large in some contexts; likewise, clientelistic electoral strategies allow some voters to benefit materially from corruption in ways that overshadow their own negative ethical evaluations of corruption itself (Anduiza, Aina, and Muñoz 2013; Boas, Hidalgo, and Melo 2019; Chang and Kerr 2017; Klašnja and Tucker 2013; Pereira and Barros 2014). The political context also shapes voters' decision-making. Voters are limited in the choices available to them (Muñoz, Anduiza, and Gallego 2016; Pavão 2018). For example, in uncompetitive or one-party-dominant political contexts, the absence of a viable alternative candidate restricts the capacity of voters to sanction a corrupt incumbent (Vera and Beatriz 2017). Or corruption may be so widespread that all alternative candidates are no less corrupt (Pavão 2018). In these ways, malfeasance becomes a weak trigger of political decisionmaking relative to other, competing factors.

We see political party leaders as much more single-minded than voters, as well as capable of coordinating party strategy across constituencies. First, party leaders are maximizing a utility function that empirically maps onto a simple goal: increasing the likelihood that the party wins or maintains a legislative majority. This 
goal requires, second, that party leaders coordinate their strategy across constituencies and present to the national electorate a slate of candidates that collectively promotes a positive party reputation. Cross-constituency coordination thus operates through the mechanism of candidate selection and deselection. Voters, as we have argued above, have utility functions that map empirically onto multiple goals, and there are often trade-offs across these goals such that voting to clean up corruption may not always be the principal goal that drives electoral choice. Voters might overlook corruption in favor of other dimensions of candidate choice. At the same time, accusations of corruption against a candidate in one constituency may spill over onto voters elsewhere, such that even if the accused were to win office again, candidates affiliated with the same party in other constituencies whose electoral margins are tighter may be negatively affected. The latter considerations may cause party leaders to withdraw renomination from candidates accused of corruption.

Party leaders are well suited to police politicians because doing so is compatible with their primary objective: to win elections. To win elections, parties need a strong party brand on both policy and valence dimensions. Valence reflects the nonpolicy reputation of the party. If the party is marred in scandal or unable to legislative effectively and pass basic legislation, its valence value is diminished. We argue that party leaders will decline to renominate corrupt politicians from their own party ranks out of concern that the national party may suffer, as voters come to perceive a weaker party brand and choose to punish even those honest candidates running under the same party label. The decisions of party leaders are thus born out of electoral anticipation, but they primarily reflect the assessments of an electorally motivated elite that coordinates party strategy across the entire country. Unlike voters, party leaders cannot easily overlook corruption as they seek to put forth a nationally viable slate of candidates without compromising the party brand. Our argument then is that party leaders anticipate the potential behavior of voters across constituencies and decline to renominate those who may make winning a legislative majority more difficult.

Nonetheless, party leaders will not always act to clean up corruption in their own ranks. Previous work shows that political elites are more responsive to issues that are salient to the public than they are to other issues (e.g., Hutchings 1998; Kollman 1998; Kuklinski and McCrone 1980; Miller and Stokes 1963). Our 
approach draws on this line of work in that we suggest - and show empirically - that party elites fail to renominate accused politicians in their ranks when corruption is a high-salience rather than a low-salience issue. Indeed, it is contexts where corruption appears to be an important consideration for voters that party elites see reason to take action. We argue that media coverage is particularly effective at increasing issue salience (King, Schneer, and White 2017) and in turn at subsequently motivating political elites to guard against a hit to the party brand by deselecting corrupt legislators. Past work by Chang, Golden, and Hill (2010) is consistent with this notion, showing that media attention is important for reining in corrupt behavior by public officials.

To illustrate our ideas, we investigate two Italian legislatures characterized by accusations of corruption: the Eleventh (1992-94) and the Sixteenth (2008-13). We document that both were periods when corruption was a salient issue for the media and public. We then compare the patterns of renomination for corrupt politicians in each of these legislatures with the patterns of renomination for accused politicians serving in each of the two prior legislatures: the Tenth (1987-92) and the Fifteenth (2006-08). These two prior legislatures were both characterized by low levels of corruption: that is, corruption was not a salient issue in either period. Our analysis shows that in the second of each set of legislatures, the more that a legislator's name was publicly associated with corruption in the press, the more likely he was to be deselected by his party. This stands in stark contrast to the first legislature in each paired set, where increased public association with corruption had no statistically distinguishable effect on the likelihood of renomination. More precisely, in the Eleventh Legislature the probability of renomination decreases from $54 \%$ to 0 as legislators move from the lowest to the highest level of public association with malfeasance. Similarly, in the Sixteenth, the probability of renomination decreases by over 50 percentage points, from $68 \%$ to $15 \%$. We find no change in the probability of renomination in the Tenth and Fifteenth Legislatures for the same change in media coverage.

In sum, we show that party leaders turn on the most publicly implicated within their own ranks, but only when corruption is salient enough to potentially damage the party brand nationally. A vigilant public drives these decisions, but an electorally minded, majority-maximizing party elite takes action. The end result is that when corruption is salient to the public, voters may not even need to hold implicated politicians accountable simply because party 
leaders "beat them to the punch." Sensing possible electoral retribution, party leaders clean up corruption before voters can.

The primary contribution of this article is our effort to reorient theoretical attention toward the importance of political elites and electoral competition rather than to offer definitive causal claims. Indeed, there has been little to no research on the effects of corruption allegations on candidate selection, let alone research on how party leaders in particular react to such situations. We are aware of only three articles that study candidate selection in contexts of widespread political malfeasance. A study using data from Puerto Rico (Camara-Fuertes and Bobonis 2015) finds a relationship between the release of municipal audit reports (that potentially reveal malfeasance) and the incumbent's decision to seek reelection. Similarly, Larcinese and Sircar (2017) report that newspaper coverage of embezzlement allegations made British Members of Parliament less likely to stand for reelection. In both cases, it appears that incriminated incumbents decided not to run again in order to avoid probable defeat. Neither of these studies examines how party leaders handle the renomination of corrupt incumbent legislators who wish to seek reelection; their focus lies with the accused themselves. The article most closely related to ours is Daniele, Galletta, and Geys (2018). It studies the effects of Italy's major corruption scandal in 1992-94 (also studied here) on local government early termination, which the authors interpret as a way that local politicians disassociate themselves from the two major parties most associated with corruption. Like our article, Daniele, Galletta, and Geys (2018) use the concept of "party brand"-in their case as a way to understand how local politicians may be tarnished when their national counterparts are incriminated. Like us as well, they are interested in how politicians, rather than voters, respond to corruption charges. We extend some of their ideas back to the national level and examine how party leaders push out incriminated politicians from within their own ranks.

Our article proceeds as follows. First, we articulate why party leaders may decide to remove an incumbent from the ballot following public association with wrongdoing. From here, we provide background information on the Italian legislatures studied, with particular emphasis on the changing public attention to corruption across each legislature. We then present our research design and our the results. We conclude the article by discussing the importance of our findings for understanding corruption in Italy, 
anticorruption campaigns more generally, and for the social scientific study of corruption.

\section{Theory: Voters, Party Elites, Valence, and Salience}

Along the lines of Grossman and Helpman (2005), we visualize a political universe that contains three actors: voters, politicians, and political parties, the last represented by party leaders. Our central assumption is that the goals and motivations of these three actors differ such that they treat scandal-tainted politicians differently. We conceive of voters as motivated by a variety of factors that may limit the specific influence of accusations of political malfeasance on the vote choice. Additionally, voters are heterogeneous, and individual voters differ in the weight they place on ethical violations by public officials compared to other factors; some are more sensitive to these violations than others. Individual politicians want to maximize the probability of their own reelection as well as their rents while in office, and they may engage in corruption depending on the interaction of these factors. Party leaders, finally, want to win elections, and specifically a majority of seats in the national legislature. Party leaders therefore will act on the basis of what is best for the party generally.

Our theory is that party leaders may deselect malfeasant legislators when malfeasance will weaken the reputation of the party - the "party brand"-in the eyes of the public. The reason is that the party brand affects the ability of the party to win votes and thereby a legislative majority. The party brand is a summary of actions and beliefs that serves as a heuristic for voters. It solves the collective-action problem of information for voters (Aldrich 2011). The brand has two components: a policy (or content) dimension and a valence dimension. We focus on the valence dimension.

The valence component reflects a party's legislative accomplishments and reputation while in office (Cox and McCubbins 2005). The valence component will be viewed positively when the party performs well by successfully passing its legislative agenda. If the party is marred by scandal or unable to pass basic legislation, its valence value is diminished. Using data from the United States, these claims have been tested empirically. Results show that voters care about the valence component (Butler and Powell 2014) and that legislators are sensitive to how their party is viewed on nonpolicy lines. Through a series of experiments, Butler and 
Powell (2014) show that voters overwhelmingly support the candidate whose party is viewed as ethical and that passes the budget on time, and that in this context, these components tend to be even more important to voters than ideological proximity. Conceptually related work has considered the establishment of the Office of Congressional Ethics (OCE) in 2008, an independent board tasked with receiving and reviewing allegations of wrongdoing against members of the US Congress. Dancey (2018) shows how leaders of both major parties have been central in the establishment and protection of the OCE over the last 10 years, working to convince reluctant rank-and-file members to support the work of the commission. This suggests that party leaders are cognizant of the need to maintain the appearance of ethical behavior and are prepared to make institutional investments to promote it.

There is no reason to think that results based on US data do not generalize: party leaders in long-standing, relatively wellfunctioning democracies typically understand the importance of the valence component and seek to protect it. In our thinking, individual incumbents seek reelection, but they may do so even while weakening the party brand through involvement in illegal activities. The incumbent may calculate that these activities do not compromise his own reelection chances. Perhaps his vote margin in the last election was large enough that he can afford to lose the votes of the small set of voters who turn away from an incriminated politician. The incumbent may estimate that the partisan composition of his electoral constituency, the strong personal ties he has built up over time with voters, or the fact many of his voters are relatively insensitive to ethical concerns will ensure that he wins reelection despite allegations of corruption. Party leaders, by contrast, may decide not to renominate an incumbent caught up in scandal, even though the individual might have won the seat had his name remained on the ballot, because of concern for the party's national vote share and ability to defend and gain seats across the country.

Because voters are heterogeneous in the weights they place on ethical violations by politicians, party leaders confront hard choices in coordinating candidate selection across constituencies. For instance, one empirical correlate of the heterogeneity in voter responses to accusations of wrongdoing lies with income. Research has found that poorer voters are more tolerant of clientelism (Weitz-Shapiro 2012) and similarly that low-income voters are less likely to react politically to accusations of corruption by public 
officials (Klašnja, Lupu, and Tucker 2017). Thus, low-income voters on average exhibit higher thresholds of tolerance for ethical violations than high-income voters. If high- and low-income voters are concentrated in different electoral constituenciesfor instance, if some regions within a country are generally much poorer than others-then we could observe political spillovers across electoral constituencies in response to revelations of wrongdoing. Corrupt legislators could be elected and reelected in constituencies with concentrations of low-income voters even as high-income voters in other constituencies defect from the party in disgust. These kinds of dynamics illustrate one scenario that would provoke party leaders to deselect corrupt legislators even when they remain likely to win their seats again.

Party leaders may not always need to protect the party brand. Corruption is not always a salient issue, and in particular may not be when only a few legislators are accused of malfeasance. A party's valence brand - and, in particular, the aspects of the valence brand related to ethics - is most likely to be damaged by revelations of corruption when the public sees such issues as important. We see media coverage as the primary mechanism through which corruption becomes salient to the public. Recent experimental research shows that the press is able to create issue salience for the public (King, Schneer, and White 2017). By inference, when newspaper stories about corruption are more frequent, the issue is likely to be more salient to the public. ${ }^{1}$ Under these conditions, it is reasonable for party leaders to deselect - that is, fail to renominatelegislators who are more tied to corruption by the press.

\section{The Context: Corruption in Italy's X-XI and XV-XVI}

Italy is one of the European countries with a particularly high reputation for corruption. In 2017, Transparency International ranked it the most corrupt nation in the European Union outside of Greece and Bulgaria. The two periods that we study were both characterized by major scandals, which embroiled large numbers of local and national politicians in accusations of corruption. The first set of legislatures we investigate - known for the Clean Hands investigations that started in 1992-received massive media publicity at the time and since then has been the subject of extensive scholarly analysis (Chang, Golden, and Hill 2010; della Porta and Vannucci 1999, among others). During Legislature XI, corruption investigations of unprecedented scale implicated thousands of 
politicians. Globally, the only comparable scandal in a democratic country in the last half-century or more has been the Brazilian Petrobras revelations that emerged in 2014 and that implicated dozens of politicians, including two former presidents. Originating with prosecutors based in Milan, the Italian Clean Hands investigations uncovered widespread, systemic political corruption going up to the highest levels of government, as well as chronic illegal party funding (della Porta 2001; Rhodes 1997; Ricolfi 1993). ${ }^{2}$ Data on public prosecutors' requests to lift parliamentary immunity shows that 218 deputies and senators $(23 \%$ of the legislators seated in the two houses) were investigated for corruption during the legislative period, which ran only two years before the scandal precipitated early elections. Judicial investigations mainly implicated members of the governing parties, especially those affiliated with the Christian Democratic Party (Democrazia Cristiana, or DC) and the Socialist Party (Partito Socialista Italiana, or PSI), which had governed the country in coalition with a number of smaller parties throughout the postwar era. ${ }^{3}$

For corruption to become salient in the minds of voters - and as a consequence, in the minds of party leaders tasked with candidate selection - the content of media coverage should shift accordingly. To assess this, we measure how often newspapers discussed corruption on their front pages over time. We examine the online archive of the Agenzia Nationale Stampa Associata (ANSA), Italy's leading wire service. Between 1982 and 2000, ANSA released a daily news summary reporting the topics discussed on the front pages of the country's main newspapers. We searched for corruption-related keywords and determined whether, on each day, corruption was discussed on the front page of at least one newspaper. We aggregated the daily data to construct monthly indexes of corruption prominence.

Figure 1 shows that newspapers gave more prominence to corruption in the period directly preceding the 1994 election (the end of Legislature XI) than in the period preceding the 1992 election (the end of Legislature X). In 1992, corruption received front-page coverage one day per month on average. In the two months preceding the 1994 election, by contrast, corruption received front-page coverage 12 days per month. Earlier in the legislative period, corruptionrelated items had appeared on the front page every other day, if not more frequently. These patterns are consistent with those reported by others drawing on different sources (e.g., Chang, Golden, and Hill 2010; Giglioli 1996; Kenny and Crepaz 2012; Vannucci 2009). 


\author{
FIGURE 1
}

Monthly Corruption Mentions in ANSA, January 1991-January

1995

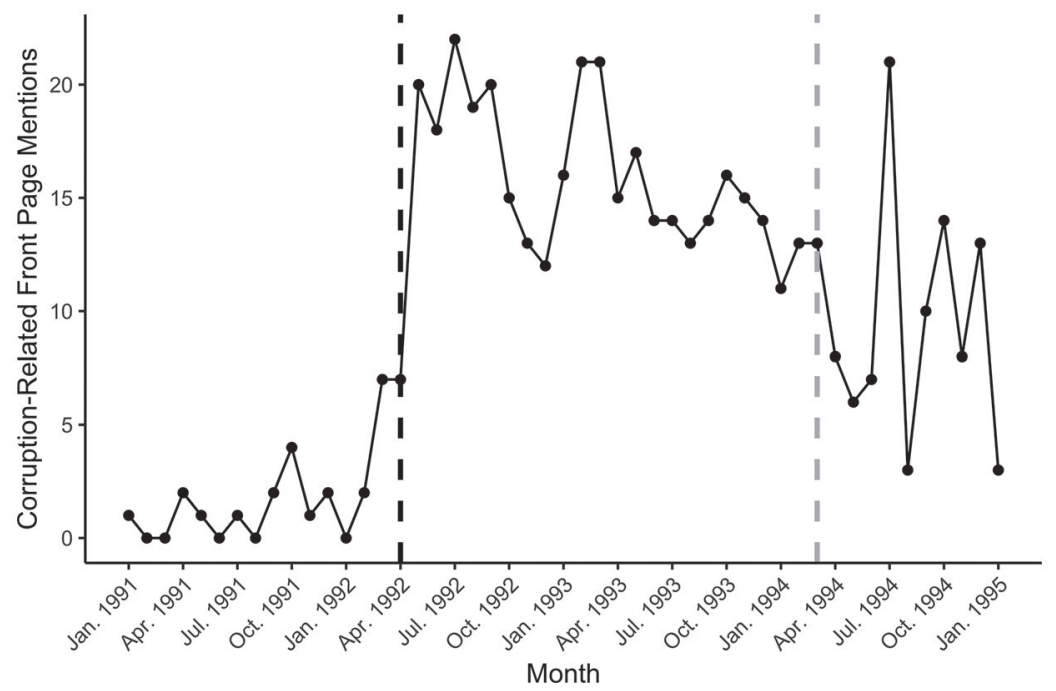

Note. Corruption-related front page mentions is the number of days per month in which at least one major Italian newspaper featured a corruption story on the front page. Search keywords: corruzione (corruption), concussione (extortion by a public official), peculato (embezzlement), abuso d'ufficio (abuse of office), corrott* (corrupted), tangent*, bustarell*, and mazzett* (bribe, kickback). Black dashed line indicates the 1992 election; gray dashed line indicates the 1994 election. Source: Agenzia Nationale Stampa Associata (ANSA) daily press reviews.

The second set of scandals that we study were less sizable but still nationally important. During Legislature XVI (2008-13), public prosecutors investigated most of Italy's regional governments for separate cases of embezzlement. ${ }^{4}$ The regional investigations developed independently of proceedings against national legislators, which then followed. Using multiple press sources, we find that as of the end of the legislature, 55 national deputies and senators $(6 \%$ of the total) were either under investigation or on trial for corruption or had avoided judgment thanks to the statute of limitations. ${ }^{5}$ Two-thirds of those accused of corruption belonged to parties in the governing coalition.

As in the Clean Hands period, in this period we also find that the media gave more coverage to corruption during the second legislature than the first. Because the ANSA news summary archive is not available for this period, we instead use that of 
La Repubblica, Italy's second most widely read daily newspaper. We replicated the ANSA procedure and determined whether, on each day, at least one article on La Repubblica's front page contained a corruption-related keyword. We again aggregated daily data to construct monthly indexes of corruption prominence. ${ }^{6}$

Figure 2 shows that La Repubblica gave greater prominence to corruption in the period immediately preceding the 2013 election than in the period preceding the 2008 election. In the two months before the 2008 election, corruption was mentioned on La Repubblica's front page five days per month on average. In the two months before the 2013 election, corruption was mentioned on the front page 11 days per month. Using a six-month timeframe, we find that corruption was covered six-and-a-half days per month before the 2008 election and 15 days per month before the 2013 election.?

The data thus show that Italy's print media gave increasing prominence to corruption in the second legislature in each of the two periods that we study. The data show that the number of press

FIGURE 2

Monthly Corruption Mentions in La Repubblica, July 2006October 2013

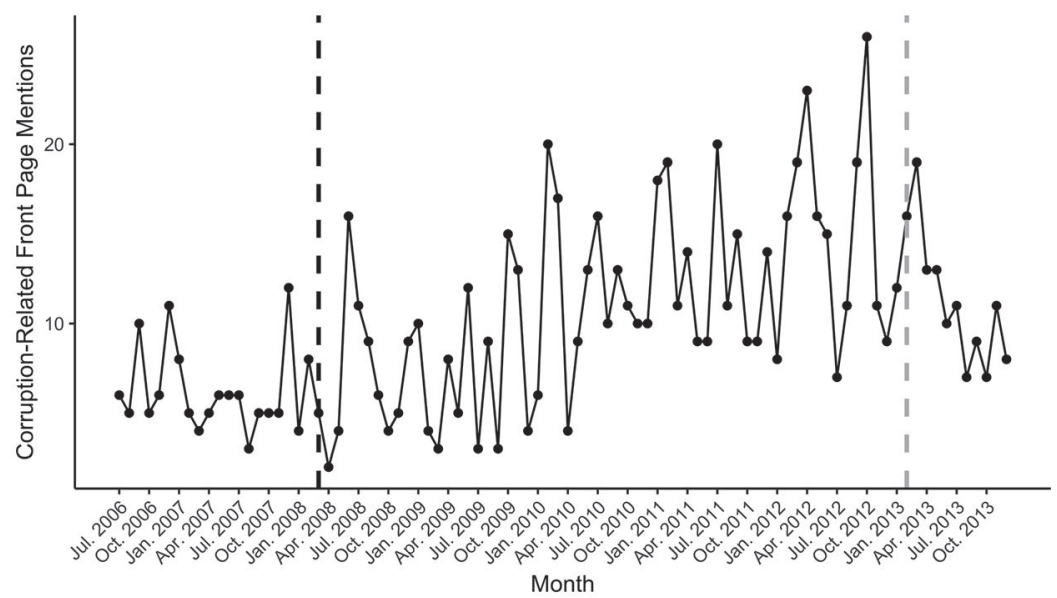

Note. Corruption-related front page mentions is the number of days per month in which at least one corruption-related article was published on the front page of La Repubblica. Search keywords: corruzione (corruption), concussione (extortion by a public official), peculato (embezzlement), abuso d'ufficio (abuse of office), tangent ${ }^{*}$, bustarell*, and mazzett* (bribe, kickback). Black dashed line indicates the 2006 election; gray dashed line indicates the 2013 election. Source: La Repubblica online archive. 
mentions was roughly equal in the two periods prior to the second elections under scrutiny. This suggests that, although the number of implicated politicians was considerably less in the episode that occurred in the 21 st century than that in the 1990s, the extent of national media coverage was similar. We thus consider the degree of issue salience in the second legislature of each pair, and the change in issue salience between the first legislature and second legislature in each, to be roughly comparable.

Our analysis is, of course, limited to newspaper coverage, and we recognize that there are other important forms of media in Italy. But television coverage is known to be correlated with newspaper coverage in the country (Asquer 2015). Similarly, mentions of corruption on Italian news websites and Twitter posts follow the publication of corruption-related references in hard-copy newspapers (Ceron 2014). Thus, coverage by online and television sources is likely to be highly correlated with newspaper coverage. This gives us confidence that newspaper mentions are a good proxy for the media information that reaches the Italian public and serve as a reasonable measure of issue salience overall. ${ }^{8}$

The extent to which corruption was presented in the press as a national problem is associated with public opinion. Data collected by the Italian National Election Studies (ITANES) found that in 1990, corruption ranked sixth (out of eight) in a ranking of the most important social problems facing the nation. We lack comparable data from 1992 or 1994, when ITANES did not ask these questions. In 1996, when ITANES surveys reincluded questions on corruption, corruption ranked as the second most serious problem in the country, following unemployment. We surmise that corruption would have been at least as salient to voters in 1994, the peak of the Clean Hands investigation.

In 2008, ITANES reported that only $2 \%$ of respondents considered corruption the most important problem facing the country, a figure that rose to $9 \%$ in 2013 . By then, $27 \%$ of Italians considered "political ethics" either the first or second most important national problem. The change in salience of the corruption issue also appeared related to views about the political class in general. In 2008, 58\% of respondents expressed little or no trust in parliament. The figure rose to $78 \%$ in 2013 . Similarly, $76 \%$ had little or no trust in political parties in 2008 compared to $89 \%$ in 2013. Eurobarometer data also corroborate the increasing importance of corruption to the Italian public in this period. In the 2007 and 2009 waves of the Eurobarometer survey, $84 \%$ of respondents 
agreed with the statement that corruption was a major problem for Italy. In 2011, this figure rose to $88 \%$, and the proportion of those who "strongly agreed" increased from $38 \%$ to $46 \%$. In addition, in $2011,60 \%$ of respondents thought that corruption had increased over the previous three years, whereas $76 \%$ of respondents thought that corruption had increased in 2013, suggesting a growing sensitivity to political malfeasance.

To summarize, data show that the media and voters generally were more attuned to corruption in the second legislative session in each of our two sets. Perhaps unsurprisingly, the political impact of the investigations that occurred in each was dramatic and almost immediate. Between 1992 and 1994, the DC, PSI, and their governing partners were discredited by corruption investigations and attacks by the media. Newspapers and television networks turned corruption into the country's major public issue, portraying the Clean Hands investigations as a moral struggle between heroic public prosecutors and decadent, self-serving political elites (Giglioli 1996). Opposition parties and citizen groups mobilized to fight corruption and those implicated. The combined effect of judicial investigations, media revelations, and public protests resulted in a massive loss of electoral support for the governing parties over the course of the legislature. Following weak results in a 1993 round of municipal elections, the DC and PSI regrouped into new parties (Sani 1995). Even that did not protect them, and in the 1994 national elections, they were all but eradicated.

Similar but less dramatic outcomes occurred during the second period we study. Between 2008 and 2013, an economic recession in conjunction with the corruption scandals fueled popular discontent with the governing parties. In late 2011, Prime Minister Silvio Berlusconi, who had led a center-right cabinet, resigned under the pressure of the sovereign debt crisis. A technocratic cabinet, headed by Mario Monti, was ushered in and remained in power until 2013. In the meantime, unemployment reached historically high levels, and the government cut public spending. During this period, media focus on corruption again seems to have influenced public opinion. Public opinion polls and the outcomes of local-level elections find increasing resentment against the political class and increasing support for the Five Star Movement (Movimento 5 Stelle, or M5S), an anticorruption, antiestablishment party that at the time held no seats in parliament (Paparo and Cataldi 2013). In the 2013 elections, voters again punished the governing parties, although not as severely as they had in 1994 
(De Sio, Cataldi, and de Lucia 2013; Garzia 2013). The vote was fragmented among the center-left coalition, the center-right coalition, and the Movimento 5 Stelle.

In Italy, as in many countries, party leaders have the capacity to protect the party brand by deselecting legislators before voters even vote. Italian candidate selection is highly centralized and remained so over the period we study despite changes to the electoral system. The 1994 election was the first held under a new mixedmember electoral system, replacing an open-list proportional system. In the Chamber of Deputies, three-fourths of the seats were now allocated by plurality rule in single-member districts, and the remaining quarter assigned through closed-list PR. The new electoral rules maintained the power of party secretariats to make candidate choice (Di Virgilio and Reed 2011; Hazan and Rahat 2010; Vignati 2004), above all because it required candidates for seats in the single-member constituencies to be affiliated with political parties that had candidates running under PR; that is, it prohibited unaffiliated candidates from running for seats in the lower house (Katz 1996, 35). As a result, candidate selection remained as closed and centralized as it had been under the PR system that the mixedmember system replaced (Lundell 2004; Wertman 1988). A 2005 introduction of closed-list PR rules further empowered national party leadership in candidate selection, marginalizing local party organizations and members (Merlo et al. 2010; Pasquino 2007). Candidate selection was particularly centralized in the center-right parties, whose top officials directly elaborated the party lists. Thus, despite the changes to Italy's electoral system that occurred over the period we study, candidate selection remained a prerogative of party elites throughout. These elites wielded a powerful instrument to protect the party brand.

A survey of the Italian press confirms that parties considered allegedly corrupt legislators as liabilities in 1994, but not in 1992 . We conducted a keyword search on the archives of Italy's two largest circulation newspapers, Corriere della Sera and La Repubblica, during the election campaigns of 1992 and 1994. ${ }^{9}$ For 1992, we were unable to find any articles discussing corruption allegations alongside candidate nominations. Either parties ignored such allegations when discussing candidate nominations or newspapers failed to report on them. In 1994, by contrast, the leadership of the main parties publicly discussed candidates' criminal records and announced that, as a general rule, legislators investigated for corruption would not be renominated. For example, the leaders of the 
Italian Popular Party (Partito Popolare Italiano) - Italy's renamed Christian Democratic Party - reportedly disagreed on whether to remove from the ballot all the investigated legislators or to make an exception for popular party figureheads. ${ }^{10}$ The secretary of the Democratic Party of the Left (Partito Democratico della Sinistra, or PDS), the renamed Italian Communist Party (Partito Comunista Italiano, or PCI), declared that his party would not make any exceptions and urged his coalition partners to do the same. ${ }^{11}$

An analysis of press sources reveals a similar shift between 2008 and 2013. In 2008, the two main parties, the Democratic Party (Partito Democratico, or PD) and the Popolo della Libertà (PdL), discussed whether to renominate legislators accused of corruption and opted for relatively flexible policies. The former pledged not to renominate legislators who had been convicted of corruption or other crimes. The leadership of the PdL reportedly recommended that regional-level organizations not renominate legislators involved in criminal proceedings, except for "those proceedings that, as we all know, are political in nature"-leaving ample room for discretion. In 2013, the two parties took a more radical approach. The PdL's leader, Silvio Berlusconi, announced that his party would not renominate any legislators currently under investigation for corruption.

The case of Nicola Cosentino illustrates the point. An influential member of Berlusconi's party, Cosentino, while serving as undersecretary for the Ministry of Economy, was implicated in two corruption investigations between 2008 and 2010. In 2012, prosecutors accused him of colluding with the Camorra, a criminal organization based in his home region of Campania, but parliament denied the judiciary authorization to arrest him. ${ }^{12}$ In 2013, when debating the composition of the party lists, Berlusconi and other PdL leaders recognized that Cosentino could mobilize thousands of voters in Campania, a region where their party faced a crucial electoral test. However, a party-commissioned survey apparently revealed that fielding Cosentino and other implicated candidates would harm the party's reputation nationally and cost even more votes. As a result, the PdL's leadership removed Cosentino from the ballot. ${ }^{13}$

We have identified two Italian legislatures where corruption was one of the country's most visible political issues, and two legislatures - those immediately preceding the legislatures characterized by malfeasance - where corruption was much less of a salient issue. We have also outlined a mechanism embedded in Italian 
party processes through which party leaders have the capacity to protect the party brand and in turn maximize the probability of maintaining or winning a legislative majority. The mechanism consists of deselecting legislators before voters cast their ballot. To test our account, we collect data on allegations of corruption and the renomination of legislators in each of the four legislatures. Below we outline these data and a research-design-equipped test whether party leaders are more likely to deselect legislators accused of malfeasance when corruption is a salient political issue.

\section{Data and Design}

We constructed an original data set of incumbents from the Italian Chamber of Deputies and the Senate in each of the four legislatures under study. ${ }^{14}$ Included in our data set is information about the characteristics of the legislator, including gender, education, age, previous work experience, and experience in the legislature. We detail these data in the online supporting information, and below.

Two variables form the core of our analysis. First, we code for whether the legislator was renominated by his or her party (or a successor party). We code a legislator as renominated regardless of whether she was nominated for the same or the other chamber. Whether the legislator was renominated or not (coded 1/0) is our dependent variable. We then code each legislator as corrupt (or not) based on whether the individual was accused of corruption by the judiciary. ${ }^{15}$ Among only those coded as corrupt, we then code for the extent to which the legislator was publicly implicated in malfeasance. We code this information from one Italian media source, La Stampa. La Stampa is a daily newspaper published in Turin with a 2012 circulation of about 250,000 . It is one of Italy's only reputable national newspapers with an online archive that covers both periods under study - 1987 to 1994 and 2006 to 2013 - that also allows electronic access to more than just front page stories. ${ }^{16}$ Other electronic archives, such as those for ANSA, Corriere della Sera, and La Repubblica, do not cover the first period we study.

We take the count of all articles containing the legislator's name and a string variable that includes at least one of the following keywords: corruzione (corruption), concussione (extortion by a public official), peculato (embezzlement), abuso d'ufficio (abuse of office), finanziamento illecito (illicit party funding), truffa ai danni dello stato (fraud against the state), truffa ai danni della regione 
(fraud against the regional government), corrott* (corrupted), and

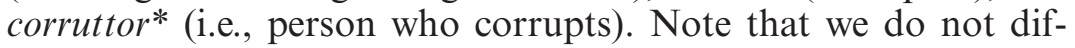
ferentiate between positively and negatively slanted coverage. But of course the context suggests that most coverage will be negative, given that the politician's name is associated with corruption. Legislators coded as noncorrupt are each assigned zero press mentions for corruption. Given its skewed distribution, we logtransform this variable (after adding 1 to each legislator, corrupt and noncorrupt, in order to remove observations that are otherwise coded zero).

Figure 3 presents histograms showing the frequency of press mentions about corruption in each legislature. Panel A gives the distribution among all legislators, and Panel $\mathrm{B}$ gives the distribution among only legislators accused of wrongdoing. As we would expect, there are more corrupt politicians and more press mentions in Legislature XI than Legislature X, and in Legislature XVI than in Legislature XV. The range of press mentions also differs across legislatures within each pair. In Legislature X, press mentions range from about zero to four (or zero to 55 on the nonlogged scale). In contrast, in Legislature XI, mentions range from zero to about 218 (nonlogged). The maximum value in Legislature XVI is smaller than in Legislature $\mathrm{XV}$, but as is clear, among corrupt

\section{FIGURE 3}

Frequency of Press Mentions

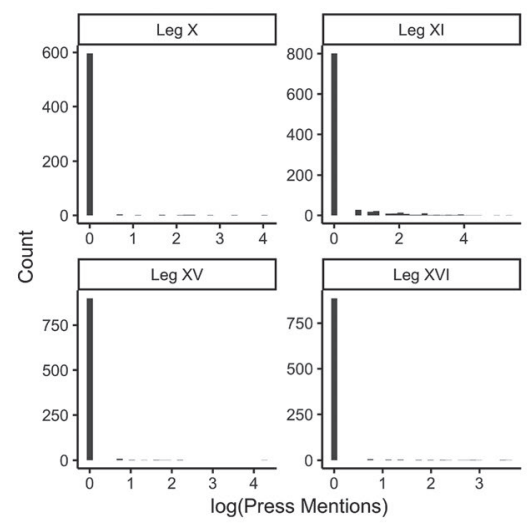

(a) All Legislators

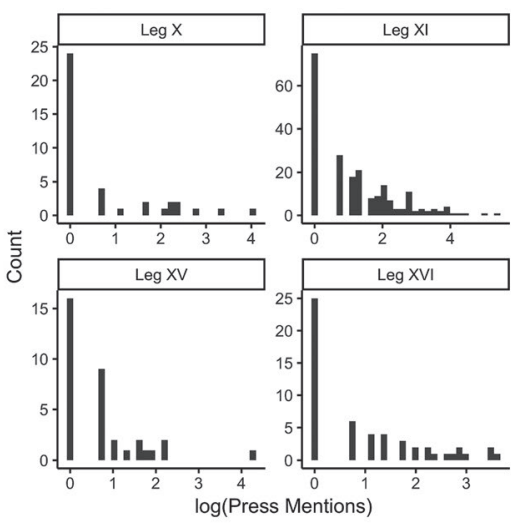

(b) Corrupt Legislators

Note. The axes in (a) and (b) are not on the same scale because the two panels reflect different samples of data, and we opt to display this information, too. 
members, more of the data are clustered closer to the maximum value in Legislature XVI than in Legislature XV. These descriptives provide some evidence that though corruption was not the norm among all all legislators, many legislators did see a significant amount of media coverage about their alleged wrongdoing. Our focus in this article is on how such media coverage shapes elite decision-making about renomination.

Our expectation is that Italian political parties will approach candidate selection differently in Legislatures XI and XVI than in Legislatures X and XV. Party elites in Legislatures XI and XVI should have been more likely to deselect legislators most implicated in corruption relative to Legislatures X and XV. To study this, we model statistically the differential influence of press mentions about corruption on renomination in the second relative to the first legislature in each pair. Doing so assumes that, in the absence of corruption becoming a more salient national political issue in the second legislative period within each pair, the rate at which political parties renominate similar types of legislators would have been constant across the two legislatures. That is, decisions about renomination should follow the same criteria across the two periods. We see no obvious theoretical reason to doubt the validity of this assumption. We are making comparisons between two back-to-back legislative sessions, making it plausible that decisions about renomination reflect variance in the issue salience rather than other factors that change over time, such as the state of the economy. Our analysis is thus a variant of the well-established difference-in-differences model. Note, though, that in our model, incumbents associated with a certain amount of press coverage about malfeasance in the first legislature are not necessarily the same individuals measured at the same level of press mentions in the second legislature. Although our theory predicts differential effects on the basis of a varied political environment, we are not assessing how the political environment changes the probability of renomination for particular legislators, or how the effect of some amount of press association with corruption changes the probability of renomination for particular politicians. Instead, our approach is to simply compare the likelihood of renomination across the two periods among the incumbent pool and at given levels of press mentions about malfeasance. ${ }^{17}$

A more theoretical assumption required for our empirical strategy is that candidates always seek to be renominated and if they are not, it is because their political party deliberately declines 
to do so. This assumption aligns with the common theory of politicians as seeking to maximize their chances of reelection. Nonetheless, it may not be empirically accurate. Students of US politics, for instance, stress that congressional representatives may engage in "strategic retirement" if they judge their chances of reelection to be too low (Jacobson and Kernell 1981). However, the concept of strategic retirement does not travel well to the political system that we study. In both periods we analyze, Italy used multimember electoral districts, meaning that each constituency elected multiple deputies and senators. This environment makes it difficult for an individual legislator to evaluate his reelection probability. It depends on vote shifts among parties but also on his position on the party list and, under an open list, on his individual popularity. Only the latter is under the direct (if incomplete) control of the incumbent; the strength of the party reflects many factors, and the candidate's position on the party list is given by party leaders, often over the objections of the candidate. Because of this, we rule out the option of strategic retirement on the part of legislators and assume, more naturally, that they all seek reelection. ${ }^{18}$

We estimate two logistic regressions of the following form, one for each pair of legislatures:

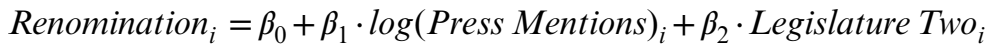

$$
\begin{aligned}
& +\beta_{3} \cdot \log (\text { Base Mentions })_{i}+\beta_{4} \cdot \text { Seniority }_{i}+\beta_{5} \cdot \text { Elite }_{i} \\
& +\beta_{6} \cdot \text { Age }_{i}+\beta_{7} \cdot \text { Job }_{i}+\beta_{8} \cdot \text { College }_{i}+\beta_{9} \cdot \text { Female }_{i} \\
& +\beta_{10} \cdot \text { GoverningParty }{ }_{i}+\beta_{11} \cdot \text { Major Party }_{i}+\beta_{12} \cdot \text { South }_{i} \\
& +\beta_{13} \cdot \log (\text { Press Mentions })_{i} \cdot \text { Second Legislature }{ }_{i}+\epsilon_{i} \text {, }
\end{aligned}
$$

where $i$ denotes an individual legislator. Our key explanatory variable is the interaction between the logged count of press mentions about corruption for the individual legislator and the dummy variable for the second legislative period in each set. The interaction term provides an estimate of the change in the slope across the two periods. It captures whether parties were significantly more punitive towards those more implicated in corruption in the second than in the first period.

As noted, we also control for a number of variables that we expect to be associated with the probability of renomination, independent of allegations of corruption or press mentions about those allegations. These are: 


\section{Raffaele Asquer, Miriam A. Golden, and Brian T. Hamel}

Base Mentions: Some legislators have a higher public profile than others, and as such appear in the newspaper more often. We expect these legislators to be more likely to be renominated. We follow Larcinese and Sircar (2017) and measure how many times each legislator appeared in the press during each legislative session. As with press mentions about corruption, we use La Stampa. Given its skewed distribution, we log-transform this variable (after adding 1 to each legislator's count of mentions).

Seniority: Historically, seniority has been associated negatively with renomination in Italy (Chang, Golden, and Hill 2010). In 1994 and 2013, party leaders had incentives to exclude the most senior incumbents, since they were perceived by the public as a particularly entrenched and self-serving elite. Incumbents with longer tenure in office should thus have lower chances of securing renomination.

Elite: Compared to backbenchers, elite legislators should have more incentives and political resources to seek reelection. We code elite representatives based on whether they hold any office within their party at the national level (e.g., member of the party's national executive). We expect party elites to be more likely to be renominated.

Age: Older legislators should be more likely to retire. Therefore, incumbent age as of the election year should be negatively associated with the likelihood of renomination.

$J o b$ :Incumbents who had relatively good jobs before entering parliament should have a greater incentive to retire since they have better outside employment options. We create a dummy variable indicating whether the legislator had a high-status nonpolitical job in the private (e.g., manager, business owner) or public sector (e.g., university professor, judge) prior to entering office. ${ }^{19}$

College: Highly educated incumbents, having more professional options outside of politics than their less educated peers, should have greater incentives to retire from office. At the same time, party leaders may put more effort into retaining them. ${ }^{20}$

Female: We have no a priori theory of the effect of gender on the likelihood of renomination. On the one hand, women are traditionally disadvantaged in Italian politics. ${ }^{21}$ On the other hand, parties that have already selected particular women to be in parliament should not discriminate against their female legislators in renomination decisions.

We may also worry about variables associated with malfeasance, and particularly with the amount of coverage the media gives those allegations. For example, certain individual characteristics 
may make it more likely that legislators are involved in corruption, and members of particular parties may be more likely to be the target of media scrutiny. We control for these confounders so as to better isolate the unique association between press mentions and renomination across the two periods. ${ }^{22}$ These are:

Governing Party: Malfeasance in the time periods under study was largely concentrated among the members of the governing parties. To account for this, we include a dummy variable measuring whether the legislator was affiliated with a party of government or not.

South: Political corruption is historically higher in southern than northern Italy. We control for this by including a dummy variable for southern (vs. nonsouthern) legislators.

\section{Results}

Table 1 presents our results. Columns 1 and 3 report the association between press mentions about corruption and renomination without control variables. The key interaction effect for Legislatures $\mathrm{X}-\mathrm{XI}$ shows a strong negative relationship between the interaction term - the (logged) number of press mentions referencing corruption and a dummy variable for Legislature XIand incumbent renomination, suggesting that political parties were more responsive to the public associations of their legislators with corruption in the second legislature than in the first. That is, party elites deselected legislators who were publicly more implicated in corrupt dealings, despite not having done so in the prior legislature.

We find a similar result when we examine the results for Legislatures XV-XVI (column 3). The interaction term between the logged number of press mentions referencing corruption and the dummy variable for the second session (Legislature XVI) is negative and statistically different from zero: political parties were more likely to deselect legislators implicated in corruption in Legislature XVI. These results are consistent with the hypothesis that party leaders were concerned about their valence brand and chose to act before voters went to the polls.

In both legislative periods, the initial effects hold when we add control variables. Estimates for Legislatures X-XI in column 2 show that age and seniority each reduce the likelihood of being renominated. More visible legislators (measured by the overall count 
22 Raffaele Asquer, Miriam A. Golden, and Brian T. Hamel

TABLE 1

Corruption Mentions and Renomination

\begin{tabular}{|c|c|c|c|c|}
\hline & (1) & (2) & (3) & (4) \\
\hline Log(Press Mentions) & $\begin{array}{c}0.091 \\
(0.332)\end{array}$ & $\begin{array}{c}0.141 \\
(0.331)\end{array}$ & $\begin{array}{c}0.315 \\
(0.431)\end{array}$ & $\begin{array}{c}0.339 \\
(0.504)\end{array}$ \\
\hline Legislature XI & $\begin{array}{l}-1.275^{* * *} \\
(0.124)\end{array}$ & $\begin{array}{l}-1.269 * * * \\
(0.136)\end{array}$ & & \\
\hline Legislature XVI & & & $\begin{array}{l}-0.795^{* * *} \\
(0.103)\end{array}$ & $\begin{array}{c}-0.164 \\
(0.140)\end{array}$ \\
\hline Log(Base Mentions) & & $\begin{array}{l}0.155^{* * *} \\
(0.037)\end{array}$ & & $\begin{array}{l}0.104^{* *} \\
(0.036)\end{array}$ \\
\hline Seniority & & $\begin{array}{l}-0.159 * * * \\
(0.040)\end{array}$ & & $\begin{array}{l}-0.164 * * * \\
(0.041)\end{array}$ \\
\hline Elite & & $\begin{array}{c}0.130 \\
(0.147)\end{array}$ & & $\begin{array}{l}0.443^{* * *} \\
(0.133)\end{array}$ \\
\hline Age & & $\begin{array}{l}-0.037 * * * \\
(0.008)\end{array}$ & & $\begin{array}{l}-0.067 * * * \\
(0.007)\end{array}$ \\
\hline Job & & $\begin{array}{r}0.236^{\dagger} \\
(0.134)\end{array}$ & & $\begin{array}{c}0.212^{\dagger} \\
(0.123)\end{array}$ \\
\hline College & & $\begin{array}{l}0.461^{* * *} \\
(0.134)\end{array}$ & & $\begin{array}{c}-0.076 \\
(0.132)\end{array}$ \\
\hline Female & -0.313 & $(0.202)$ & $0.258^{\dagger}$ & $(0.156)$ \\
\hline Governing Party & & $\begin{array}{r}-0.323^{*} \\
(0.131)\end{array}$ & & $\begin{array}{l}-0.645^{* * *} \\
(0.150)\end{array}$ \\
\hline South & & $\begin{array}{l}0.311^{*} \\
(0.132)\end{array}$ & & $\begin{array}{c}-0.117 \\
(0.121)\end{array}$ \\
\hline $\begin{array}{l}\text { Log(Press Mentions }) \mathrm{x} \\
\text { Legislature XI }\end{array}$ & $\begin{array}{c}-1.599 * * * \\
(0.399)\end{array}$ & $\begin{array}{c}-1.759 * * * \\
(0.402)\end{array}$ & & \\
\hline $\begin{array}{l}\text { Log(Press Mentions) } \mathrm{x} \\
\text { Legislature XVI }\end{array}$ & & & $\begin{array}{c}-1.002^{*} \\
(0.490)\end{array}$ & $\begin{array}{c}-0.924^{\dagger} \\
(0.556)\end{array}$ \\
\hline Intercept & $\begin{array}{l}1.395 * * * \\
(0.102)\end{array}$ & $\begin{array}{l}2.790 * * * \\
(0.398)\end{array}$ & $\begin{array}{l}1.123 * * * \\
(0.077)\end{array}$ & $\begin{array}{l}4.908^{* * *} \\
(0.431)\end{array}$ \\
\hline Observations & 1,555 & 1,538 & 1,834 & 1,675 \\
\hline
\end{tabular}

${ }^{\dagger} p<0.1,{ }^{*} p<0.05,{ }^{* *} p<0.01,{ }^{* * *} p<0.001$.

of media mentions), southern legislators, those with previous professional experience, and those with college degrees are all more likely to be renominated, all else equal. Results in column 4 for Legislatures XV-XVI also show that affiliation with a governing party, age, and seniority reduce the likelihood of being renominated. In this period, as in the earlier one, we also find statistical 
evidence that more visible politicians and party elites were more likely to be renominated.

For ease of interpretation, we take the model estimates shown in columns 2 and 4 and calculate the predicted probability of renomination within each legislature at the minimum and maximum value of logged press mentions about corruption (within the legislative pair). We hold all other variables at the mean value in each legislative pair. These probabilities isolate the changing political environment across each legislature (within each pair) and show how particular levels of press mentions differently correlate with renomination over time. That is, these probabilities allow us to easily observe how the effect of the same number of press mentions differs across the two legislatures. Figure 4 presents these results. As the data depicted in the figure show, we find that in Legislatures $\mathrm{X}$ and $\mathrm{XV}$, moving from the minimum to maximum value of press mentions about corruption has no discernible impact on the probability of renomination. In contrast, in Legislatures XI and XVI, the probability of renomination dramatically decreases from the minimum to the maximum value. Indeed, in Legislatures X-XI, the probability of renomination decreases from about $54 \%$ to $0 \%$. Likewise, in Legislatures XV-XVI, the probability of renomination decreases by over 50 percentage points, from $68 \%$ to $15 \%$. These predicted probabilities document our key finding: as legislators become increasingly associated with accusations of wrongdoing, party leaders seek to protect the party reputation by deselecting

FIGURE 4

Predicted Probabilities of Renomination

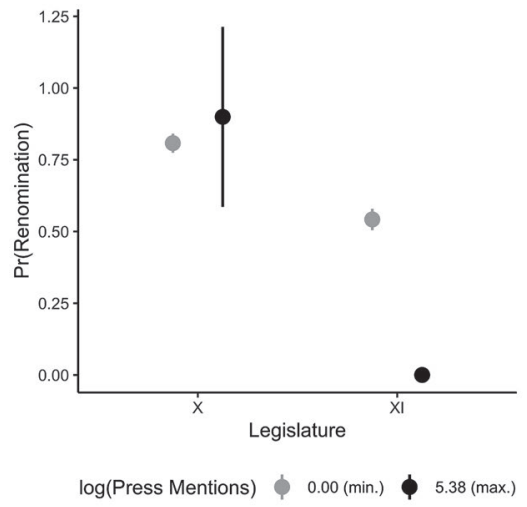

(a) Legislature X-XI

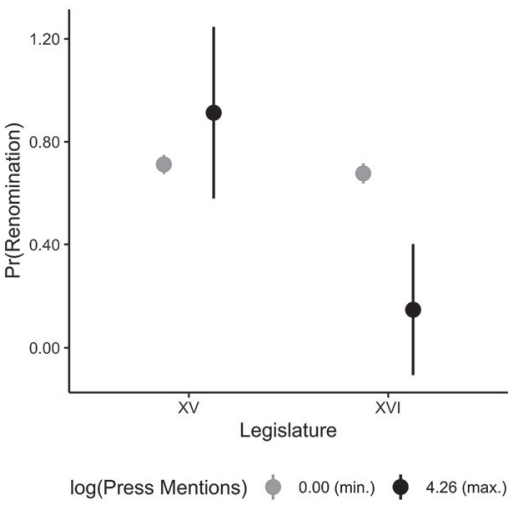

(b) Legislature XV-XVI 
them, thereby removing them from the ballot. But they only do so when the media and the public are attuned to these allegations and see corruption as a politically important issue.

\section{Discussion}

According to Transparency International, Italy continues to exhibit corruption levels well above average in western Europe. ${ }^{23}$ Scholars of the country lament that the Clean Hands investigations failed to curb corruption (della Porta and Vannucci 2012) and may have even worsened it (Vannucci 2009). As evidence, analysts contend that "the political class has only partially 'renewed' itself, with a large number of politicians being 'recycled' from the parties of the "First Republic"" (della Porta and Vannucci 2007, 830 ) and that "all the indicators available on the diffusion of corruption instead signal high and constant levels" (831). This view has been widely diffused by the Italian press and is arguably conventional wisdom (Di Nicola 2003).

Other investigations present evidence that contradicts the dominant view. Statistical analyses of criminal activities on the part of civil servants show a substantial drop in the decades after the Clean Hands investigations as well as declines in the prices paid for construction of public infrastructure (Acconcia and Cantabene 2008; Del Monte and Cantabene 2007). This quantitative work suggests that the systems that previously linked political parties, civil servants, and construction companies in elaborate schemes involving kickbacks for campaign financing may have been permanently disrupted with the Clean Hands investigations. And indeed, the scandals that underlie the second set of legislatures we study in this article involve geographically localized phenomena and forms of corruption distinct from party campaign financing, a fact admitted even by those who contend that corruption remains a major ongoing problem in Italy (della Porta, Sberna, and Vannucci 2015).

Arbitrating between these views is difficult given the kinds of data available. The reason is that if quantitative indicators of corruption show falling rates, there is no way to know if this is because corruption is actually in decline or if it has instead become more hidden and difficult to uncover. For instance, if fewer civil servants are charged with crimes related to corruption, we do not know if this is because fewer of them commit such crimes or if investigators are doing a less good job in uncovering these crimes, 
perhaps because those who commit them are taking greater care to hide them. Given these inferential problems, it is unsurprising that many contend that the Clean Hands investigations were not successful in reducing corruption in Italy: analysts would have strong grounds for this claim if observed levels of corruption increased, but they could be correct even if levels decreased.

Our study contributes directly to this debate. Our data show that after the Clean Hands investigations, national legislators implicated in corrupt activities were not successful at remaining in public life as elected officials when the press was vigilant in making corruption a publicly salient issue. Our research design is well suited for making descriptive inferences of this sort because it is constructed to examine parallel trends in different legislative periods when, arguably, only a single determining factor has changed: namely, the overall extent of public interest in corruption. Although our design still suffers from limitations - there may be changes in addition to that of the intensity of political salience that occur between the legislative periods - it offers an improvement over a simple examination of trends over time. We thus contend that our findings are more persuasive than arguments based on weaker research designs, and in particular on raw counts of phenomena. In addition, our analysis systematically studies the ability of incriminated politicians to reenter public office, whereas other studies draw on only anecdotal evidence.

Ironically, the role of the press in publicizing corruption and thereby arousing anticorruption public opinion contributes to what we believe is the erroneous interpretation that corruption remains as frequent as ever in Italian public life. It is when the press publicizes corruption that public opinion is aroused, and national politicians under investigation are driven from public office-but this is precisely when it may well appear to a naive observer that there is more rather than less corruption in public life. The frequency of anecdotal reports in the media serves simultaneously to prevent the recurrence of corruption and to suggest that the problem remains common. But frequent reporting on corruption may be misleading if it is interpreted to suggest that the underlying phenomenon is worse.

Our analysis offers grounds for reinterpreting the aftereffects of the Clean Hands investigations. As we have said, many have concluded that these investigations were not successful in reducing political corruption in Italy. We disagree. The new data that 
we report in this article show a substantial reduction in political corruption in Italy, both during and in the years following the Clean Hands investigations. In particular, we demonstrate the importance of the press in combination with electorally motivated, legislative majority-maximizing political party leaders in keeping corrupt politicians from reentering public office. The data that we analyze show that the most corrupt politicians are typically not able to continue running for and winning public office. Instead, their careers are forcibly interrupted when the press goes to work making corruption a salient public issue. This is a politically and policy-relevant finding. In particular, the demonstration effects of Italy's anticorruption efforts (especially the Clean Hands investigations) for ongoing anticorruption campaigns in Latin America make it important that scholars provide accurate assessment of how effective these activities have been.

Our findings carry implications for understanding the success of anticorruption campaigns more generally. Anticorruption campaigns can be successful. But success requires ongoing vigilance by three separate groups: the public, which must continue to maintain a norm against corruption and publicly condemn it; the press, which must continue to publicize it; and party gatekeepers, who must shift from facilitating to preventing their corrupt peers from reentering public office. Note as well that in the case we study, the judiciary seems important only in the background: politicians were removed from public office despite an absence of judicial prosecution or conviction. Whether these processes will be paralleled in more recent anticorruption campaigns, such as those in Brazil, Mexico, and Guatemala, remains to be seen.

\section{Conclusion}

Our article is motivated by one key question: Under what circumstances are politicians held accountable for wrongdoing? This question is particularly important given what we already know: although voters dislike corruption, corrupt politicians often win reelection. We suggest here that party elites may be crucial in eliminating corruption in government. Party leaders are single-minded relative to voters: they seek to maintain or win a legislative majority. Doing so requires a strong and positive party brand. Voters, in contrast, behave with multidimensional goals, weighing a number of different factors when choosing among candidates. Voting 
against the most corrupt candidate may not be in the best interest of many voters. Party leaders are able to efficiently police their members because doing so can positively contribute to the party's electoral fortunes nationally. And party leaders are most likely to do so when the public is attuned to corruption, when the potential political consequences of corrupt behavior are greatest. In short, our argument is that party leaders anticipate potential voter behavior, and out of concern that the presence of malfeasant incumbent politicians may hurt the party more broadly, opt to deselect these legislators.

The results of our data analyses support this observation. We have found a negative and statistically significant relationship between the number of newspaper mentions of corruption allegations for individual members of Italy's Chamber of Deputies and Senate and the likelihood of renomination-but only when corruption is a salient political issue to the public. We argue that these findings suggest political parties were concerned that their national vote shares would suffer as voters in other constituencies across the country punished candidates associated with parties that renominated the most publicly visible transgressors - even if individual implicated candidates might have achieved reelection in their own constituencies. This heterogeneity in constituency-level electoral outcomes can be thought of as an outcome of the geographic concentration of corruption-tolerant (perhaps low-income) voters in some constituencies and, conversely, that of corruption-intolerant (high-income) voters elsewhere. ${ }^{24}$ We conclude that party leaders are essential to cleaning up corruption. They have the incentives and the political authority to do so before voters even have the opportunity to remove implicated legislators.

We recognize that our findings may elicit alternate interpretations. One is that party elites suddenly experience moral revulsion at the behavior of their partisan compatriots. Our analysis does not allow us to distinguish between this possibility and our focus on cross-constituency coordination because we have no way to know which specific groups of voters would have withdrawn electoral support from parties had they renominated malfeasant legislators and no way to peer into the hearts of party leaders. Future research should carefully consider mechanisms that may be at work, perhaps by investigating more directly than our data permit us the relationships between corruption, vote choice, and income (cf. Weitz-Shapiro 2014). ${ }^{25}$ 
Our findings point to the importance of the media in ensuring electoral accountability. Some studies find that the more information on malfeasance voters receive from the media, the more likely they are to vote corrupt incumbents out of office (Chang, Golden, and Hill 2010; Costas-Perez, Solé-Ollé, and SorribasNavarro 2012; Ferraz and Finan 2008; Larreguy, Marshall, and Snyder 2014). These studies assume a direct accountability channel from voters to their political representatives. But before voters vote, political party leaders choose whether to renominate incumbents. We have demonstrated that in Italy in two different periods, separated by decades and characterized by different electoral rules, party elites appear to have operated similarly to reduce the exposure of their parties to allegations of corruption. They did so by refusing to renominate incumbents whose names appeared more often in the press in conjunction with corruption allegations. By enabling voters to identify incumbents accused of corruption, the media contributes to removing them from office. But party elites - and not voters - are the channel through which removal occurs. Our study thus shows how politicians implicated in corruption are removed from office despite the fact that voters generally reelect such incumbents - when they are on the ballot.

This study suggests that future research on corruption, malfeasance, and governance should pay more attention to the role of party leaders in stemming bad behavior and should seek to understand why they behave as they do, given how voters typically behave. Previous work has focused overwhelmingly on whether and how voters hold politicians accountable. This approach has often proved normatively disappointing, since voters appear to be poorly positioned to exercise the accountability function ascribed to them (Dunning et al. 2019). Our results suggest that party leaders may be the best hope of cleaning up corruption, for no other reason than because doing so improves the chances for their party of winning elections.

Raffaele Asquer Independent Researcher <raffasquer@gmail. com>. Miriam A. Golden Peter Mair Chair in Comparative Politics, Department of Political and Social Sciences, European University Institute, Via dei Roccettini 9, I-50014 San Domenico di Fiesole (FI), Italy<miriam.golden@eui.eu>. Brian T. Hamel Ph.D. Student, Department of Political Science, University of California, 


\section{Los Angeles, 4289 Bunche Hall, Los Angeles, CA 90095-1472 <bhamel@ucla.edu>.}

\section{NOTES}

We thank Gianmarco Daniele, Jeff Lewis, and Eleanor Woodhouse for helpful comments and conversations. Golden acknowledges the Academic Senate of the University of California, Los Angeles for funding and the hospitality of the Center for Advanced Study in the Behavioral Sciences at Stanford University. Hamel acknowledges the National Science Foundation Graduate Research Fellowship program for support.

1. Empirically, although King, Schneer, and White (2017) show that the press has the capacity to shape public interest, it is also true that preexisting public interest may motivate the press to report on certain issues. The casual direction is not relevant to our argument.

2. Our metric of corruption in this period is requests to parliament by the judiciary to remove the parliamentary immunity of members of the Chamber of Deputies and the Senate in order to proceed with investigations into suspected wrongdoing. These have been studied in prior research by Chang, Golden, and Hill (2010), Nannicini et al. (2013), and Ricolfi (1993), among others. For details on the data, see the online supporting information.

3. Eighty-four percent of the deputies and senators investigated for corruption belonged to parties in the governing coalition. In the Socialist Party and the Social Democratic Party (Partito Socialista Democratico Italiano, or PSDI), also affiliated with the government, almost one out of two legislators was investigated.

4. See, for example, "Spese folli, la grande abbuffata delle Regioni. Indagini in tre su quattro," Il Fatto Quotidiano, December 14, 2013.

5. For details on the data, see the online supporting information.

6. Mincigrucci and Stanziano (2017) analyze data that show that La Repubblica's coverage of corruption is more extensive than that of some other Italian newspapers, such as Corriere della Sera. They interpret this as possible evidence that the former plays a watchdog role in Italy, providing additional justification for our analysis of La Repubblica's coverage.

7. Results are similar if we aggregate the data by year. In the year before the 2013 election, corruption was two-and-a-half times more prominent than in the year before the 2008 election.

8. We also examined Google Trends data for the term "corruzione" (corruption) from 2006 to 2013, the time period covering Legislatures XV and XVI. The Trends report returns an average for each month in the time series. The value given indicates the amount of interest in "corruzione" as a proportion of all searches on all topics on Google over the full period in Italy. The metric is meant to provide some insight about relative popularity. The month with the largest amount of interest is given the value 100 (the month with the highest search interest in corruption was October 2012), and all other month averages can be 


\section{Raffaele Asquer, Miriam A. Golden, and Brian T. Hamel}

interpreted relative to that. The 2006 election was held in April 2006. In April 2006, the Trends data gives a value of 54. The 2013 election was held in February 2013. The Trends data for April 2013 gives a value of 83. These data are therefore consistent with the idea that corruption was a more salient political issue in the 2013 election than in the 2006 election.

9. We searched for the following strings: "corruzione (corruption) AND candidati (candidates)" and "indagati (investigated) AND candidati (candidates)." The timeframe is the 30 -day period preceding the deadline for the submission of candidate lists.

10. "Segni Martinazzoli, scontro sugli inquisiti," Corriere della Sera, February 9, 1994; "Il gran carnevale di Segni e Martinazzoli," La Repubblica, February 12, 1994. 1994.

11. "Le liste di Occhetto a prove di inquisito," La Repubblica, January 29,

12. "Cosentino referente dei Casalesi. Chiesto di nuovo l'arresto del parlamentare del Pdl," Corriere della Sera, July 12, 2011.

13. "Cosentino e gli impresentabili," Corriere della Sera, January 15, 2013 and "Il sondaggio elettorale di Berlusconi: Gli impresentabili? Una zavorra per il Pdl," Il Fatto Quotidiano, January 20, 2013.

14. The two chambers enjoy equivalent powers and are elected concurrently using similar rules, making it appropriate to study both.

15. In the online supporting information, we detail how we coded for corruption.

16. Available at http://www.lastampa.it/archivio-storico/index.jpp.

17. Table A1 in the online supporting information provides summary statistics about the characteristics of legislators in each legislature. These generally show that the composition of the legislatures is similar within back-to-back pairs.

18. In the estimations below, we also handle the issue of age-related retirement with a control variable for age.

19. Unlike their US counterparts, Italian legislators are allowed to keep their jobs unless they are employed by the government or have full-time salaried occupations (Merlo et al. 2010, 43-44). For instance, lawyers, who comprised $15 \%$ and $12 \%$ of Legislature XI and Legislature XVI, respectively, generally continued to work for their law firms even after election.

20. The college premium in Italy is lower than in most developed countries (OECD 2005). As a result, college-educated incumbents do not have as strong an incentive as in other countries to leave politics for work in the private sector.

21. The proportion of female deputies and senators increased from $9 \%$ to $21 \%$ between Legislature XI and Legislature XVI. Italy still had the lowest rate of female parliamentary representation in the Eurozone in 2012.

22. In the online supporting information, we explain how each variable is coded, and we provide information about data sources.

23. For 2017 data, see https://www.transparency.org/news/feature/europe_ and_central_asia_more_civil_engagement. Accessed August 8, 2018. 
24. One implication of this theory is that corrupt legislators will cluster geographically in the less economically developed parts of the country, which was generally the case in Italy in the periods we study, when corruption was more prevalent in the South.

25. We do not test these relationships because we do not have, for example, constituency-level per capita income data.

\section{REFERENCES}

Acconcia, Antonio, and Claudia Cantabene. 2008. "A Big Push to Deter Corruption: Evidence from Italy." Giornale degli Economisti e Annali del Economia 67: 75-102.

Aldrich, John H. 2011. Why Parties? A Second Look. Chicago: University of Chicago Press.

Anduiza, Eva, Gallego Aina, and Jordi Muñoz. 2013. "Turning a Blind Eye: Experimental Evidence of Partisan Bias in Attitudes Towards Corruption." Comparative Political Studies 46: 1664-92.

Asquer, Raffaele. 2015. Media Coverage of Corruption and Renomination: Evidence from Italian Parliamentary Elections. Ph.D. diss., University of California, Los Angeles.

Basinger, Scott J. 2013. "Scandals and Congressional Elections in the PostWatergate Era.” Political Research Quarterly 66: 385-98.

Boas, Taylor C., Daniel F. Hidalgo, and Marcus André Melo. 2019. "Norms Versus Action: Why Voters Fail to Sanction Malfeasance in Brazil." American Journal of Political Science 63: 385-400.

Butler, Daniel M., and Eleanor Neff Powell. 2014. "Understanding the Party Brand: Experimental Evidence on the Role of Valence." Journal of Politics 76: 492-504.

Caḿara-Fuertes, Luis Raúl, and Gustavo J. Bobonis. 2015. "Challenging Corrupt Politicians? Audits, Electoral Selection, and Accountability in Municipal Elections." Unpublished paper, University of Puerto Rico-Río Piedras and University of Toronto.

Carlson, Matthew M., and Steven R. Reed. 2018. Political Corruption and Scandals in Japan. Ithaca, NY: Cornell University Press.

Ceron, Andrea. 2014. "Twitter and the Traditional Media: Who Is the Real Agenda Setter?" Unpublished paper, University of Milan.

Chang, Eric C.C., Miriam A. Golden, and Seth J. Hill. 2010. "Legislative Malfeasance and Political Accountability.” World Politics 62: 177-220.

Chang, Eric C.C., and Nicholas A. Kerr. 2017. "An Insider-Outsider Theory of Popular Tolerance for Corrupt Politicians." Governance 30: 67-84.

Chong, Alberto, Ana L. De La O, Dean Karlan, and Leonard Wantchekon. 2015. "Does Corruption Information Inspire the Fight or Quash the Hope? A Field Experiment in Mexico on Voter Turnout, Choice and Participation." Journal of Politics 77: 55-71. 


\section{Raffaele Asquer, Miriam A. Golden, and Brian T. Hamel}

Costas-Perez, Elena, Alberto, Solé-Ollé, and Pilar Sorribas-Navarro. 2012. "Corruption Scandals, Voter Information, and Accountability." European Journal of Political Economy 28: 469-84.

Cox, Gary W., and Mathew D. McCubbins. 2005. Setting the Agenda: Responsible Party Government in the U.S. House of Representatives. New York: Cambridge University Press.

Dancey, Logan. 2018. "Ethics and the Party Brand: The Case of the Office of Congressional Ethics." Congress \& the Presidency 45: 125-44.

Daniele, Gianmarco, Sergio Galletta, and Benny Geys. 2018. "Abandon Ship? Party Brands and Politicians' Responses to Political Scandal.” Working Paper 2018/03, Institut d'Economia de Barcelona (IEB).

De Sio Lorenzo, Matteo Cataldi, and Federico de Lucia. 2013. Le Elezioni Politiche 2013. Rome: Centro Italiano Studi Elettorali (CISE).

Del Monte, Alfredo, and Claudia Cantabene. 2007. "Anticorruption Campaigns and the Determinants of Corruption in Europe." World Review of Entrepreneurship, Management and Sustainable Development 3: 170-91.

della Porta, Donatella. 2001. "A Judges' Revolution? Political Corruption and the Judiciary in Italy." European Journal of Political Research 39: 1-21.

della Porta, Donatella, Salvatore Sberna, and Alberto Vannucci. 2015. "Centripetal and Centrifugal Corruption in Post-Democratic Italy." In Italian Politics: The Year of the Bulldozer, ed. Chris Hanretty and Stefania Profeti. Vol. 30. New York: Berghahn Books: 198-217.

della Porta, Donatella, and Alberto Vannucci. 1999. Corrupt Exchanges: Actors, Resources, and Mechanisms of Political Corruption. New York: Aldine de Gruyter.

della Porta, Donatella, and Alberto Vannucci. 2007. "Corruption and AntiCorruption: The Political Defeat of 'Clean Hands' in Italy.” West European Politics 30: 830-53.

della Porta, Donatella, and Alberto Vannucci. 2012. "When Anti-Corruption Policy Fails: The Italian Case Eighteen Years After the Mani Pulite Investigations." In The Social Construction of Corruption in Europe, ed. Dirk Tänzler, Konstadinos Maras, and Angelos Giannakopoulos. London: Routledge: 133-161.

Di Nicola, Andrea. 2003. "Dieci anni di lotta alla corruzione.” In Rapporto sulla criminalità in Italia, ed. Marzio Barbagli. Bologna: Il Mulino: 109-133.

Di Virgilio, Aldo, and Steven R. Reed. 2011. "Nominating Candidates Under New Rules in Italy and Japan: You Cannot Bargain with Resources You Do Not Have." In A Natural Experiment on Electoral Law Reform, ed. Daniela Giannetti and Bernard Grofman. Studies in Public Choice 24. New York: Springer: 61-75.

Dunning, Thad, Guy Grossman, Macartan Humphreys, Susan D. Hyde, Craig McIntosh, and Gareth Nellis, ed. 2019. Metaketa I: Information, Accountability, and Cumulative Learning. New York: Cambridge University Press. 
Ferejohn, John. 1986. "Incumbent Performance and Electoral Control." Public Choice 50: 5-25.

Ferraz, Claudio, and Frederico Finan. 2008. "Exposing Corrupt Politicians: The Effect of Brazil's Publicly Released Audits on Electoral Outcomes." Quarterly Journal of Economics 123: 703-45.

Garzia, Diego. 2013. "The 2013 Italian Parliametary Election: Changing Things So Everything Stays the Same." West European Politics 36: 1095-1105.

Giglioli, Pier Paolo. 1996. "Political Corruption and the Media: The Tangentopoli Affair." International Social Science Journal 48: 381-94.

Grossman, Gene, and Elhanan Helpman. 2005. "A Protectionist Bias in Majoritarian Politics.” Quarterly Journal of Economics 120: 1239-82.

Hamel, Brian T., and Michael G. Miller. 2019. "How Voters Punish and Donors Protect Legislators Embroiled in Scandal.” Political Research Quarterly 72: $117-31$.

Hazan, Reuven Y., and Gideon Rahat. 2010. Democracy Within Parties: Candidate Selection Methods and Their Political Consequences. Oxford: Oxford University Press.

Hutchings, Vincent L. 1998. "Issue Salience and Support for Civil Rights Legislation Among Southern Democrats.” Legislative Studies Quarterly 23: 521-44.

Jacobson, Gary C., and Samuel Kernell. 1981. Strategy and Choice in Congressional Elections. New Haven, CT: Yale University Press.

Katz, Richard S. 1996. "Electoral Reform and the Transformation of Party Politics in Italy." Party Politics 2: 31-53.

Kenny, Paul D., and Michele Crepaz. 2012. "Corruption Scandals and Political Crises: The 'Free Press' and Democracy in Italy.” Unpublished paper, Australian National University and Trinity College.

King, Gary, Benjamin Schneer, and Ariel White. 2017. "How the News Media Activate Public Expression and Influence National Agendas.” Science 358: 776-80.

Klašnja, Marko, Noam Lupu, and Joshua A. Tucker. 2017. "When Do Voters Sanction Corrupt Politicians?” Unpublished paper, Georgetown University, Vanderbilt University, and New York University.

Klašnja, Marko, and Joshua A. Tucker. 2013. "The Economy, Corruption, and the Vote: Evidence from Experiments in Sweden and Moldova." Electoral Studies 32: 536-43.

Klašnja, Marko, Joshua A. Tucker, and Kevin Deegan-Krause. 2016. "Pocketbook vs. Sociotropic Corruption Voting." British Journal of Political Science 46: 67-94.

Kollman, Ken. 1998. Outside Lobbying: Public Opinion and Interest Group Strategies. Princeton, NJ: Princeton University Press.

Kuklinski, James H., and Donald J. McCrone. 1980. "Policy Salience and the Causal Structure of Representation." American Politics Quarterly 8: 139-64.

Larcinese, Valentino, and Indraneel Sircar. 2017. "Crime and Punishment the British Way: Accountability Channels Following the MPs' Expenses Scandal." European Journal of Political Economy 47: 75-99. 


\section{Raffaele Asquer, Miriam A. Golden, and Brian T. Hamel}

Larreguy, Horacio A., John Marshall, and James M. Jr. Snyder. 2014. "Revealing Malfeasance: How Local Media Facilitates Electoral Sanctioning of Mayors in Mexico." Working Paper No. 20697. National Bureau of Economic Research (NBER).

Lundell, Krister. 2004. "Determinants of Candidate Selection: The Degree of Centralization in Comparative Perspective." Party Politics 10: 25-47.

Merlo, Antonio, Vincenzo Galasso, Massimiliano Landi, and Andrea Mattozzi. 2010. "The Labor Market of Italian Politicians." In The Ruling Class: Management and Politics in Modern Italy, ed. Tito Boeri, Antonio Merlo, and Andrea Prat. Oxford: Oxford University Press: 7-95.

Miller, Warren E., and Donald E Stokes. 1963. "Constituency Influence in Congress." American Political Science Review 57: 45-56.

Mincigrucci, Roberto, and Anna Stanziano. 2017. "Il coverage della corruzione tra il 2004 and il 2015 in Italia: controllo di virtüo populismo penale?" Problemi dell' Informazione 42: 201-27.

Muñoz Jordi, Eva Anduiza, and Aina Gallego. 2016. "Why Do Voters Forgive Corrupt Mayors? Implicit Exchange, Credibility of Information and Clean Alternatives." Local Government Studies 42: 598-615.

Nannicini, Tommaso, Andrea Stella, Guido Tabellini, and Ugo Troiano. 2013. "Social Capital and Political Accountability." American Economic Journal: Economic Policy 5: 222-50.

OECD. 2005. "Education at a Glance 2005." Unpublished paper. http://www. oecd.org/education/skills-beyond-school/educationataglance2005-home. htm

Paparo, Aldo, and Matteo Cataldi. 2013. "Le ondate del 5 stelle fra 2010 e 2013." In Le elezioni politiche 2013, ed. Lorenzo De Sio Matteo Cataldi, and Federico de Lucia. Number 4, Dossier CISE, Centro Italiano Studi Elettorali (CISE).

Pasquino, Gianfranco. 2007. "Tricks and Treats: The 2005 Italian Electoral Law and its Consequences." South European Society and Politics 12: 79-93.

Pavão, Nara. 2018. "Corruption as the Only Option: The Limits to Electoral Accountability." Journal of Politics 80: 996-1010.

Pereira, Carlos, and Lucia S. G. Barros. 2014. "Tolerance of Corruption or Ideological Blindness?" Unpublished paper, Getulio Vargas Foundation and FGV-EAESP.

Peters, John G., and Susan Welch. 1980. "The Effects of Charges of Corruption on Voting Behavior in Congressional Elections." American Political Science Review 74: 697-708.

Przeworski, Adam, Susan C. Stokes, and Bernard Manin, ed. 1999. Democracy, Accountability, and Representation. Cambridge: Cambridge University Press.

Rhodes, Martin. 1997. "Financing Party Politics in Italy: A Case of Systemic Corruption." West European Politics 20: 54-80.

Ricolfi, Luca. 1993. L'ultimo Parlamento. Sulla fine della prima Repubblica. Rome: La Nuova Italia Scientifica. 
Sani, Giacomo. 1995. "Toward the Second Republic? The Italian Parliamentary Election of March 1994." In Deconstructing Italy: Italy in the Nineties, ed. Salvatore Sechi. Berkeley: University of California: 39-69.

Vannucci, Alberto. 2009. “The Controversial Legacy of 'Mani Pulite:' A Critical Analysis of Italian Corruption and Anti-Corruption Policies." Bulletin of Italian Politics 1: 233-64.

Rojas, Sof ia Beatriz Vera. 2017. "The Heterogenous Effects of Corruption: Experimental Evidence from Peru." Unpublished paper, University of Pittsburgh.

Vignati, Rinaldo. 2004. "Trasformazioni dei partiti politici, democrazia interna e selezione dei candidati." In Le trasformazioni dei partiti politici, ed. Francesco Raniolo. Soveria Mannelli: Rubbettino Editore: 121-142.

Weitz-Shapiro, Rebecca. 2012. "What Wins Votes: Why Some Politicians Opt Out of Clientelism." American Journal of Political Science 56: 568-83.

Weitz-Shapiro, Rebecca. 2014. Curbing Clientelism in Argentina: Politics, Poverty, and Social Policy. New York: Cambridge University Press.

Weitz-Shapiro, Rebecca, and Matthew S. Winters. 2013. "Lacking Information or Condoning Corruption: When Do Voters Support Corrupt Politicians?" Comparative Politics 45: 418-46.

Weitz-Shapiro, Rebecca, and Matthew S. Winters. 2017. "Can Citizens Discern? Information Credibility, Political Sophistication, and the Punishment of Corruption in Brazil." Journal of Politics 79: 60-74.

Welch, Susan, and John R. Hibbing. 1997. "The Effects of Charges of Corruption on Voting Behavior in Congressional Elections, 1982-1990." Journal of Politics 59: 226-39.

Wertman, Douglas. 1988. "Italy: Local Involvement, Central Control." In Candidate Selection in Comparative Perspective: The Secret Garden of Politics, ed. Michael Gallagher and Michael Marsh. London: Sage: 145-169.

Winters, Matthew S., and Rebecca Weitz-Shapiro. 2016. "Who's in Charge Here? Direct and Indirect Accusations and Voter Punishment of Corruption." Political Research Quarterly 69: 207-19.

\section{Supporting Information}

Additional supporting information may be found in the online version of this article at the publisher's web site:

The supporting information includes summary statistics for the variables included in our models, aswell as additional analyses.

Table A1. Summary Statistics

Table A2. Corruption Mentions and Renomination-Major vs. Minor Parties 